\title{
PENGARUH DESAIN ORGANISASI TERHADAP KINERJA DINAS PENANAMAN MODAL DAN PELAYANAN TERPADU SATU PINTU (DPMPTSP) DI KOTA PALEMBANG
}

\author{
Akhmad Mustain \\ Sekolah Tinggi Ilmu Administrasi Bala Putra Dewa Palembang \\ Email : akhtain@tahoo.co.id
}

\begin{abstract}
ABSTRAK
Penelitian ini dilatarbelakangi oleh rendahnya kinerja Dinas Penananamn Modal dan Pelayanan Terpadu Satu Pintu (DPMPTSP) Kota Palembang. Penyebabnya adalah desain organisasi DPMPTSP belum sepenuhnya mendukung kebutuhan, sistem dan tujuan dari pelayanan terpadu satu pintu bidang perizinan. Penelitian ini bermaksud menguji pengaruh desain organisasi terhadap kinerja organisasi melalui metode survei. Pengumpulan data dilakukan melalui kuesioner dengan teknik analisis menggunakan Structural Equation Model (SEM).

Hasil penelitian menjelaskanbahwadesain organisasi memilikipengaruh yangbesarterhadapkinerja organisasi. Besarnya pengaruh desain organisasi terhadap kinerja organisasi tersebut ditentukan oleh faktor struktur, proses dan manusia. Artinya bahwa perubahan faktor struktur, proses dan manusia dalam desain organisasi dapat memberikan dampak yang besar bagi kinerja organisasi. Proses organisasi menjadi faktor palingkuat dalam merefleksikan desain organisasi dibandingkan strukturdan manusia. Berdasarkan simpulan penelitian diperoleh hasil bahwa Desain organisasi memiliki pengaruh terhadap kinerja organisasi. Pengaruh desain organisasi terhadapkinerja organisasi tersebutditentukan oleh faktor struktur, proses danmanusia dalam organisasi. Adapunfaktor proses merupakan faktoryang palingmerefleksikandesain organisasi dibandingkan faktor lain dalam desain organisasi yaitu struktur dan manusia. Struktur yang dibuat masih sangat hierarkis, proses organisasi dalam pelayanan perizinan belum terintegrasi. Penataan sumber daya manusia dalam organisasi belum mendukungkebutuhan tenaga teknik dalam organisasi, sehingga akan menimbulkan kinerja dalammenghasilkanpelayananperizinanyangoptimalbelumtercapai.
\end{abstract}

Kata Kunci: Desain organisasi, Kinerja organisasi, Proses Organisasi

\section{PENDAHULUAN}

Persoalan penting yang dihadapi organisasi pemerintah adalah masih buruknya kinerja pelayanan yang dihasilkan oleh birokrasi. Pelayanan masih lamban, berbelit-belit, kaku dan cenderung tidak tanggap terhadap kebutuhan masyarakat. Kinerja sektor publik oleh sebab itu terus menjadi topik besar yang diminati baik oleh praktisi maupun akademisi di seluruh dunia. Pendapat Abramson, et.al yang dikutip oleh Sole (2009: 3) menyatakan bahwa pengukurankinerja merupakan elemen penting untuk meningkatkan kinerja organisasi itu sendiri dan juga akuntabilitas. Namun demikian pengukuran kinerja tidak pernah secara efektif dilakukan di beberapa organisasi sektor publik. Alasan yang sering dikemukakan adalah pemahaman yang kurang tentang kerangka kerja yang dapat digunakan untuk mengukur kinerja organisasi publik. Hal tersebut menyebabkan peningkatan kinerja organisasi menjadi sulit diwujudkan (Sole, 2009: 9).

Kinerja organisasi dalam urusan perizinan merupakan salah satu bentuk kegagalan kinerja organisasi sektor publik yang terus mengemuka. Penelitian Hardiyansyah (2011) menjelaskan bahwa pelaksanaan pelayanan perizinan memang masih memiliki banyak kelemahan seperti mekanisme dan prosedur pelayanan yang panjang, tidak ada kepastian waktu penyelesaian dan biaya tinggi, kurangnya transparansi informasi baik mengenai ketentuan, mekanisme prosedur, persyaratan maupun proses penyelesaiannya; dan kurang profesionalnya pelayananyangdiberikanolehaparat. 
Dalam rangka meningkatkan kinerja pelayanan perizinan, Menteri Dalam Negeri telah mengeluarkan Peraturan Menteri Dalam Negeri No 138 Tahun 2017 tentang Penyelenggaraan Pelayanan Terpadu Satu Pintu Daerah. Pelayanan terpadu satu pintu adalah suatu bentuk pelayanan dimana mulai dari pendaftaran sampai dengan penyerahan izin dilaksanakan di dalam satu tempat. Tujuan mendasamya adalah penyederhanaan proses pelayanan perizinan, yaitu meliputi pemangkasan tahapan prosedur, pengurangan jumlah biaya, pengurangan waktu pemrosesan, pengurangan jumlah dokumen serta menghilangkan praktek pungutan di luar ketentuan.

Penyelenggaraan pelayanan terpadu satu pintu (PTSP) bidang perizinan di Kota Palembang diselenggarakan oleh Dinas Penananamn Modal dan Pelayanan Terpadu Satu Pintu (DPMPTSP). BerdasarkanPeraturan WalikotaPalembangNomor 41 Tahun 2018 Tentang Pendelegasian sebagian kewenangan di Bidang Perizinan dan Non Perizinan Kepada Dinas Penanaman Modal dan Pelayanan Terpadu Satu Pintu disebutkan bahwa tujuan dari Pendelegasian sebagian kewenangan di Bidang Perizinan dan Non Perizinan Kepada Dinas Penanaman Modal dan Pelayanan Terpadu Satu Pintu dilaksanakan dalam rangka penataan dan pengembangan mekanisme kontrol yang efektif dan efisien untuk meningkatkan pelayanan publik sesuai kebutuhan dan harapan masyarakat. Dengan demikian Walikota telah menyerahkan tanggungjawab untuk penandatanganan dokumen izin kepada Kepala DPMPTSP. Oleh sebab itu proses penyelesaian perizinan mulai dari pendaftaran sampai dengan pengambilan dokumen izin diselenggarakan oleh DPMPTSP. Namun dalam Peraturan walikota tersebut juga dijelaskan bahwa pengambilan keputusan perizinan yang berskalabesaryangmempengaruhibaik dalam pertumbuhan perekonomian, penyerapantenaga kerja, kemajuan suatu wilayah, dan berdampak lingkungan, terlebih dahulu harus memperoleh persetujuan Walikotaagar selaras dengan Rencana Tata Ruang dan Wilayah Kota. Adapun perizinan tertentu sebagaimanadimaksudantaralaian:

a. Perizinan untuk pendirian hotel bintang 3 (tiga) ke atas;

b. Perizinanuntukpendirianrumahsakitbesar;

c. Perizinan untuk pendirian pusat perbelanjaan skala besar; d. Perizinan untuk penerbitan izin usaha industri skala menengah;dan

e. Perizinan dan rekomendasi untuk penerbitan izin pembangunan, pengoperasian pelabuhan sungai dandanau(pelabuhankhususregional dalamkota).

Untuk mewujudkan tujuan organisasi diperlukan adanya aturan, sistem, prosedur dan hierarki yang saling mendukung (Istianto, 2011). Faktor-faktor tersebut di Kota Palembang belum sepenuhnya mendukung penyelenggaraan pelayanan perizinan yang sesuai harapan. Pada sisi aturan disebutkan bahwa DPMPTSP merupakan organisasi yang bertugas melakukan koordinasi dengan dinas teknis terkait untuk menyelenggarakan pelayanan perizinan. Sehingga jelas bahwa DPMPTSP di desain bukan sebagai organisasi yang memiliki kewenangan penuh atas perizinan. Padahal sistem yang harus berlaku di DPMPTSP adalah mulai dari pendaftaran sampai dengan penerbitan izin ada di DPMPTSP. Hal tersebut sesuai amanat Permendagri No138 Tahun 2017. Akan tetapi pada kenyataannya prosedur yang dibuat masih panjang dan berbelit-belit. Dalam aturan, DPMPTSP tidak dirancang memiliki bidang-bidang teknis yang terintegrasi. Kewenangan melakukan penilaian terhadapobjekizin tetapberada pada dinas-dinas teknis. Pengambilan keputusan di DPMPTSP harus melalui mekanisme pengambilan keputusan antar dinas teknis. Oleh sebab itu dari sisi hierarki penyelenggaraan pelayanan perizinanmasihmelewati banyaktingkatan.

Dengan demikian jelas bahwa persoalan rendahnya kinerja DPMPTSP dalam bidang pelayanan perizinan disebabkan karena desain organisasi B DPMPTSP belum mendukung pada pencapaian tujuan pelayanan terpadu satu pintu. Padahal ditegaskan oleh Andersen (2002: 344) bahwa mengapa organisasi terus secara aktif mencari model organisasi yang tepat disebabkan karena desain organisasi dapat memberi dampak bagi kinerja organisasi. Desain organisasi dalam pendapat tersebut digambarkan sebagai solusi penting yang banyak dilakukan oleh organisasi. Hal tersebut dilakukan karena desain organisasi diyakini merupakan faktor penting untuk meningkatkan kinerja organisasi (Stanwick and Pleshko, 1994; Andersen, 2002; Galbraith,2002; Stanford,2005; Lawler IIIddan Worley, 2009).

Oleh sebab itu penelitian ini bermaksud untuk mengetahui dan menganalisis besamya pengaruh desain organisasi terhadapkinerja organisasi. Tujuannya adalah untuk menemukan konsep atau proposisi baru 
yang berkaitan dengan faktor penting dalam desain organisasi yang dapat meningkatkan kinerja organisasi sebagai sumbangan pemikiran dalam pengembangan Ilmu Administrasi Publik.

\section{METODE PENELITIAN}

Penelitian ini dilakukan dengan menggunakan pendekatan penelitian kuantitatif karena penelitianinimenguji teori tertentu dengan carameneliti hubungan antarvariabel. Metode yang digunakan adalah survey. Pengumpulan data menggunakan kuesioner (Cresswell, 2002). Untuk menganalisis besamya pengaruh antar variabel dan pengujian hipotesis dilakukan melalui metode Structural Equation Model(SEM)(Solimun, 2008).

\section{HASIL DAN PEMBAHASAN}

Penelitianini melakukan pengujian pengaruh variabel desain organisasi terhadap kinerja organisasi. Untuk mengukur variabel kinerja organisasi digunakan indikator yang pernah dijelaskan oleh Boyne, et al (2006: 14) yang meliputi dimensi outputs, efficiency, effectiveness, responsiveness and equity. Sedangkan untukmengukur variabel desain organisasi penelitianini mengacu pada pendapat Lawler III dan Worley (2009: 188) yang menjelaskan bahwa dalam desain organisasi terdapat faktor struktur, proses dan manusia yang dapat dijadikanacuandalammelihatdesainorganisasi.

Pengaruh desain organisasi terhadap kinerja organisasi dijelaskan melalui hasil analisis SEM. Hasil analisis menjelaskan bahwa terdapat pengaruh yang besar dari desain organisasi terhadap kinerja organisasi. Besamya pengaruh desain organisasi terhadap kinerja organisasi tersebut ditentukan oleh faktor struktur, proses dan manusia. Perubahan dalam faktor struktur, proses dan manusia dalam desain organisasi dapat memberikan dampak bagi kinerja organisasi. Artinya bahwa hipotesis dalam penelitian ini dapat dibuktikan.

Penelitian ini juga menjelaskan bahwa faktor yang paling merefleksikan variabel desain organisasi adalah proses organisasi. Hal tersebut memperkuat pemyataan Stanford (2005: 14) yang menjelaskan bahwa memang desain organisasi tidak hanya menyangkut persoalan struktur tetapi juga proses yang adadidalam organisasi. Menurut Gibson, et.al (1989:9) proses dalam organisasi merupakan sumber kehidupan dalam mempengaruhi keberhasilan desain organisasi. Hasil penelitian Lee Chan and Lee Kyu (2007:26) dan Dawud (2009) juga menjelaskan bahwa struktur dan proses dalam organisasi memiliki pengaruh terhadap kinerja organisasi. Namun demikian dalampenelitian ini menemukan bahwa proses organisasi memiliki dominasi yang kuat dalam desain organisasi. Sehingga penelitian ini dapat memperjelas pendapat sebelumnya.

Hasil penelitian tersebut dilandasi oleh kenyataan di lapangan bahwa desain penataan organisasi di daerah melalui PP No. 18 Tahun 2016 lebih mempersoalkan organisasi semata-mata sebagai persoalan struktur. Hal ini terlihat dari esensi kebijakan yang lebihmenekankan pada tiga hal:

1. Penyeragaman nomenkelatur kelembagaan daerah

2. Penentuan jumlah kelembagaan daerah yang berbasis pada hasil perhitungan atas variabel jumlah penduduk, luas wilayah, dan jumlah APBD

3. Perumpunankelembagaan daerah, meskipunjuga menentukan beberapa perubahan lain seperti perubahan eselonisasi pejabat daerah dan lain sebagainya

Tidak mengherankan bila perubahan yang terjadi dalam desain organisasi di daerah hanya dimaknai perubahan struktur dan nama organisasinya saja. Dalam hal proses dan kebijakan alokasi sumberdaya manusia tidak pernah disesuaikan dengan kebutuhan dan tujuan organisasi serta kondisi riil organisasi birokrasi. Hal tersebut terlihat dalam desain organisasi pelayanan perizinan melalui organisasi penyelenggara pelayanan perizinan terpadu satu pintu. Hasil penelitian ini menunjukkan bahwa desain organisasi yang sekarang berlaku ternyata belum mencerminkan penataan proses organisasi dan penempatan sumberdaya manusia secara tepat. Artinya adalah desain organisasi pelayanan terpadu satu pintu masih belum secara optimal dapat mempercepat proses pelayanan perizinan seperti yang telah di amanatkan oleh peraturan, dalam hal ini Peraturan Menteri Dalam Negeri Nomor 138 Tahun 2017 tentang Penyelenggaraan Pelayanan Perizinan Terpadu Satu PintuDaerah.

Kenyataan di lapangan menunjukkan bahwa desain organisasi DPMPTSP belum mencerminkan sebagai organisasi penyelenggara pelayanan terpadu, karena masing-masing bagiannya masih bekerja sendiri-sendiri sesuai dengan tugas pokok dan fungsi masing-masing. Oleh sebab itu kinerja yang dihasilkan DPMPTSPmenjadi belum maksimal. 
Hasil penelitian Muktiali (2006) dapat menjelaskan bahwa terdapat permasalahan internaldan eksternal dalam penyelenggaraan Pelayanan Terpadu Satu Pintu, salah satunya adalah masih ditanganinya perizinan oleh dinas-dinas terkait. Hal ini menyebabkan kinerja yang berbelit-belit. Padahal Stanwick dan Pleshko (1995:176) sudah mengingatkan bahwa salah satu prinsip penyelenggaraan organisasi terpadu sangat mensyaratkan adanya koordinasi dalam pelaksanaan tugasmelaluitaskforceataukomite.

Belum optimalnya kinerja DPMPTSP dengan demikian jelas disebabkan desain organisasi DPMPTSP yang belum konsisten dengan kebutuhan, tujuan serta sistem organisasi DPMPTSP. Struktur yang dibuat masih sangat hierarkis. Proses organisasi dalam pelayanan perizinan belum terintegrasi. Penataan manusia dalam organisasi juga belum mendukung kebutuhan tenaga teknik dalam organisasi. Pada akhimya kinerja DPMPTSP dalam menghasilkan pelayanan perizinan yang optimal belum tercapai. Artinya bahwa desain organisasi yang dicerminkan olehfaktor struktur, prosesdan manusia yangtidaktepat akanberdampakpadakinerjaorganisasi yangburuk.

Mengacu pada pendapat Stanford (2005: 14) bahwa desain organisasi harus mempertimbangkan elemen-elemen kebutuhan dan strategi dalam organisasi. Hal tersebut disebabkan desain organisasi merupakan alat penting yang membantu pencapaian tujuan organisasi. Lebih lanjut dia mengatakan bahwa ketika organisasi ingin meningkatkan kinerja organisasi maka akan diperlukan peningkatan hubungan dan interaksi antara bagian/komponen yang satu dengan yang lainnya yang membentuk sebuah departemen. Merubah hubungan pada satu komponen akan berdampak pada bagian yang lain.

Desain organisasi merupakan proses bagaimana organisasimengorkestra faktor-faktor dalam organisasi seperti struktur, proses dan manusia (Lawler III \&Worley 2009: 196). Secara tegas Stanford (2005: 14) menyatakan bahwa desain organisasi memiliki pengaruh terhadap kinerja organisasi. Desain organisasi menurutnya "is not simply about ,structure" but the design principles that under-pin it". Oleh sebab itu melihat desain organisasi tidak hanya sekedar melihat struktumya saja tetapi lebih dari itu ada prinsip-prinsip tertentuyangharusdibangundidalamnya.

Pada kenyataannya desain organisasi yang ada di daerah memang dirancang, disahkandan dikirimdari pemerintah pusat. Seperti halnya di DPMPTSP Kota Palembang, struktur, proses dan sistem penataan sumberdaya manusianya sejatinya masih sama dengan desain organisasi sebelumnya. Hampir semua aspek dalam prosedur diatur dengan ketat sehingga orang tidak leluasa menciptakan prosedur sendiri, maka kondisi ini disebut sebagai overbirokrasi (Keban, 2008: 138).

Desain organisasi yang sekarang berlaku berdasarkan PP 18 tahun 2016 memang hanya memposisikan DPMPTSP sebagai sekretariat saja, padahal DPMPTSP dituntut untuk menyelenggarakan pelayanan perizinan yang sederhana, cepat dan berkepastian. Dijelaskan oleh Osborne dan Plastrik (2004:6) bahwa desain organisasi harus menyesuaikan dengan strategi. Galbraith (2002) juga menjelaskan bahwa desain organisasi dibuat memang untuk mendukung strategi yang berlaku sehingga kinerja organisasidapatmeningkat.

Posisi DPMPTSP dalam lingkup organisasi pemerintah daerah bila merujuk pendapat Mintzberg (1992:10) memiliki fungsi sebagai supporting staff. Dijelaskan olehnya bahwa supporting staff is about organizationtendstoaddstaff unitsof adifferent nature, not to effect standardization but to provide indirect service to it self. Mengacu pada pendapat tersebutmaka jelaslah mengapa DPMPTSPtidak pernahbisaoptimal dalam penyelenggaraan fungsinya, karena DPMPTSP didesain untuk melakukan pelayanan ke dalam, seperti halnya Badan Kepegawaian dan Pengembangan Sumber Daya Manusia, Badan Perencanaan PembangunanDaerah dan sebagainya. Dengan rentang kendali yang sangat luas, DPMPTSP menjadi sangat sulit untuk mewujudkan kinerjanya yang optimal Sebagai bagian dari proses reformasi birokrasi, pembentukan organisasi DPMPTSP ibarat teknologi baru yang sulit diterapkan. Organisasi pemerintah daerah terbiasa bekerja dengan spesialisasi yang tinggi. Sangat sulit untuk mengitegrasikan unit-unit tersebut dalam bentuk koordinasi yang sifatnya tidak terstruktur dengan jelas. Hal tersebut disebabkan birokrasi selalu mendasarkan diri pada aturan baku dan bertangggungjawab berdasarkan urutan rentang kendali. Artinyabahwaimplementasi kebijakan tentang Organisasi Perangkat Daerah membutuhkan perubahan yang cukup mendasar dalam organisasi birokrasi, itulah sebabnyamengapaimplementasinyamenjadiberat.

Mengacupada pemikiran Van Materdan Van Horn (1975) yang dikutip oleh Wahab (2005:79) bahwa implementasi kebanyakan akan berhasilapabila perubahan yang dikehendaki relatif sedikit, sementara kesepakatanterhadaptujuan terutama dari merekayang 
mengoperasikan program di lapangan relatif tinggi. Sistem DPMPTSP menuntut perubahan dalam organisasi secara drastis sehingga sulit diterapkan.

Oleh sebab itu berdasarkan hasil penelitian di lapangan dapat dijelaskan bahwa belum optimalnya pelayanan perizinan disebabkan karena desain organisasi yang ada belum konsisten dalam mendukung kebutuhan, sistem dan tujuan organisasi perizinan terpadu. Struktur yang dibuat belum berorientasi pada penyederhanakan pelayanan perizinan. Proses organisasi dalam pelayanan perizinan masih berbelit-belit karena belum terintegrasi. Penataan manusia dalam organisasi juga belum mendukung kebutuhan tenaga teknik dalam organisasi. Menurut pendapat Nadler dan Tusman (1997: 34) dalam desain organisasi dikenal adanya teori congruence yang menurut mereka didefinisikan sebagai the degree to wich the needs, demans, goals or objectives and structure of component are consistant with those of other.

Organisasi birokrasi masih belum konsisten dalam menerapkan desain organisasi berdasarkan kebutuhan, sistem dan tujuan organisasi. Selain itu kepribadian khusus yang dimiliki organisasi birokrasi juga tidak pernah dipertimbangkan dalam menerapkan desain organisasi. Artinya adalah terdapat logika diskontinuitas (logic of discontinuity) dalam penerapan suatu desain organisasi birokrasi. Faktor struktur, proses dan manusia dalam organisasi belum di desain untuk mendukung kebutuhan, sistem dan tujuan pelayanan terpadusatupintu.

\section{SIMPULAN DAN SARAN}

1. Desain organisasi memiliki pengaruh terhadap kinerja organisasi. Pengaruh desain organisasi terhadap kinerja organisasi tersebut ditentukan oleh faktor struktur, proses dan manusia dalam organisasi. Adapun faktor proses menupakan faktor yang palingmerefleksikan desainorganisasi dibandingkan faktor lain dalam desain organisasi yaitustrukturdanmanusia.

2 Strukturyang dibuatmasih sangathierarkis, proses organisasi dalam pelayanan perizinan belum terintegrasi. Penataan sumber daya manusiadalam organisasi belum mendukung kebutuhan tenaga teknik dalam organisasi, sehingga akan menimbulkan kinerja dalam menghasilkan pelayananperizinanyangoptimalbelumtercapai.

Disarankan melalui penelitian ini adalah sebagai berikut:
1. Perlunya bagi organisasi pemerintah daerah adalah membangun desain organisasi yang lebih mengutamakan proses organisasi agar dapat meningkatkan kinerja organisasi. Hal tersebut dapat dilakukan melalui identifikasi keselunuhan aktivitas organisasi yang diperlukan untuk disesuaikan dengan tujuan, kebutuhan, sistemdan regulasiyangada.

2 Kemudian pembuatan Standard Operational Procedure (SOP) tentang pelayanan perizinan terpadu yang menggabungkan semua aktivitas unit instansi yang terlibat, Membentuk bidangbidangteknis sesuai dengan nama-nama perizinan yang dilayani sesuai dengan kebutuhan pelayanan yang terpadu. menerapkan sistem jaringan komputer yang menghubungkan antar instansi sebagai sarana penyimpanan database yang diperlukansemuaunitinstansi yangterlibat.

\section{DAFTAR PUSTAKA}

Andersen, 2002. Organizational Design: Two Lessons to Learn Before Reorganization, International Journal of Organizational Theory and Behaviour, Vol5No3:343-358.

Boyne, G.A,Meier, Toole.Jr and Walker, 2006. Public Service Performance, Perspective Measurement and Management, New York: Cambridge UniversityPress.

Chan,Lee \& Kyu, Lee, 2007. Capabilities,process, and Performance of Knowledge Management: A Structural Approach, Human Factors and ErgonomicsinManufacturing, vol 17,p.21-41.

Creswell, John, 2002. Desain Penelitian, Pendekatan Kualitatif dan Kuantitatifterjemahan Angkatan III \& IV KIK-UI.Jakarta:KIKPress.

Dawud, Joni, 2009. Pengaruh Desain Organisasi Pemerintah Daerah Terhadap Kualitas Pelayanan di Kawasan Perkotaan (Studi di Kawasan Perkotaan Cipanas Kabupaten Cianjur), Disertasi Universitas Padjajaran.

Galbraith, J.R, Downey \& Kates, 2002. Designing Dynamic Organization, New York: Amacom. 
Gibson, James L, Ivancevich, John M \& Donnelly, James H, 1989. Organisasi, perilaku, Struktur dan Proses,Jakarta:Erlangga.

Hardiyansyah, 2011. Pengaruh Komunikasi Terhadap Kualitas Pelayanan Publik (Studi Tentang Pelayanan Izin Mendirikan Bangunan pada Dinas Tata Kota, Kota Palembang), Disertasi Universitas Padjadjaran. Istianto, Bambang,2011. Demokratisasi Birokrasi, Jakarta: Mitra Wacana Media.

Keban, Yeremias, 2008. Enam Dimensi Strategis Administrasi Publik, Konsep, Teori dan Isu, Edisi 2, Yogyakarta:GavaMedia.

Lawler III, E \& Worley, C, 2009. Designing Organizations That Are Built to Change, The Organization of The Future: Visions, Strategies, and Insights on Managing in New Era Frances Hesselbein and Marshall Goldsmith (Ed). San Fransisco, Jossey-Bass.

Mintzberg, H. (1992). Structure in Five, New Jersey: Prentice-Hall Inc.

Muktiali, Muhammad, 2006. Kajian Evaluasi Penerapan One Stop Service (OSS) di Jawa Tengah, Jurnal Tata Kelola, vol 8, Semarang: Universitas Diponegoro.

Nadler, D.A \& Tushman, M.L, 1997. Competing by Design: The Power of Organizational Architecture, New York : Oxford University Press.

Osborne, D \& Plastrik, P. 2004. Banishing Bureaucracy: The five Strategies for Reinventing Government(terjemahan),Jakarta:PPM.

Stanford, Naomi, 2005. Organization Design: The Collaborative Approach, Elsevier ButterworthHinemann, Linacre House, Jordan Hill, Oxford.

Solimun, 2008. Memahami Metode Kuantitatif Mutakhir, Structural Equation Modeling \& Partial Least Square, Malang: Universitas Brawijaya.
Sole, Fransisco, 2009. A Management Model and Factors Driving Performance in Public Organizations, Measuring Business Excellence, $Q$ Emerald Group Publishing Limited, ISSN 1368-3047. Vol 13 No 4:.3-11.

Stanwick,Peter \& Pleshko, Larry, 1995. Relationship of Environmental Characteristics, Formalized Planning and Organizational Design to Performace, The International Joumal of OrganizationalAnalysis, Vol3 No2::175-197.

Wahab, Solichin. 2005. Analisis Kebijaksanaan, Dari Formulasi ke Implementasi Kebijaksanaan Negara, Jakarta: Bumi Aksara. 